\title{
Effects of annual changes in primary productivity and ocean indices on breeding performance of tropical roseate terns in the western Indian Ocean
}

\author{
David Monticelli ${ }^{1,2, *}$, Jaime A. $\operatorname{Ramos}^{3}$, Graham D. Quartly ${ }^{4}$ \\ ${ }^{1}$ Royal Belgian Institute of Natural Sciences, Section of Conservation Biology, 29 Rue Vautier, 1000 Brussels, Belgium \\ ${ }^{2}$ Laboratory of Tropical and Subtropical Forestry, Unit of Forest and Nature Management, \\ Gembloux Agricultural University, 2 Passage des Déportés, 5030 Gembloux, Belgium \\ ${ }^{3}$ Institute of Marine Research (IMAR), Department of Zoology, University of Coimbra, 3004-517 Coimbra, Portugal \\ ${ }^{4}$ National Oceanography Centre, Southampton (NOCS), Empress Dock, Southampton, Hampshire SO14 3ZH, UK
}

\begin{abstract}
We assessed the influence of inter-annual changes in primary productivity and local, regional and large scale ocean indices on the breeding parameters of roseate terns Sterna dougallii on Aride Island, Seychelles, western Indian Ocean. Productivity (chicks per breeding pair), timing of breeding and clutch and egg sizes were monitored annually for $8 \mathrm{yr}$ and correlated with local ocean productivity (denoted by Sea-viewing Wide Field-of-view Sensor, SeaWiFS, estimates of chlorophyll concentration, CC), sea surface temperature and indices recording the status of the Indian Ocean Dipole and of El Niño. The rate of increase in CC between mean laying date and CC peak value was positively related to roseate tern productivity and mean clutch size over the 1998 to 2005 study period. Colony productivity seemed also to be influenced by the Multivariate El Niño Index. In most years, the breeding phenology of roseate terns corresponded to the local increase in CC around Aride, and failure to adjust timing of reproduction to the timing of the phytopankton bloom decreased the probability of breeding success. This is the first study showing that a tropical seabird species is sensitive to inter-annual variations in the intensity and timing of the phytoplankton bloom, which should be connected to annual variations in the availability of its main fish prey (juvenile goatfishes). Overall, these patterns indicate that the reproduction of this top marine predator is dictated by the temporal variability in oceanographic conditions. We suggest that CC data available over the world's oceans may be a useful tool to develop models predicting the fate of colonies of inshore feeding seabirds when other, more conventional, monitoring methods cannot be used.
\end{abstract}

KEY WORDS: Sterna dougallii · Breeding · Inter-annual variation · Ocean productivity · El Niño · SeaWiFS $\cdot$ Seabird ecology $\cdot$ Indian Ocean

\section{INTRODUCTION}

The availability of food for seabirds is a major factor influencing reproductive success and is primarily affected by environmental determinants such as weather and physical oceanographic factors (Dunn 1975, Smithers et al. 2003, White 2004). To date, however, few studies have been able to relate seabird reproductive output with a direct measure of prey availability. This relationship has been established for temperate regions (Safina et al. 1988, Aebischer et al.
1990, Frederiksen et al. 2006), but has proven to be more difficult for tropical areas because seasonal patterns in marine productivity appear to be less regular and data on marine food stocks are relatively scarce (see Ballance et al. 2006). Nevertheless, ocean and climatic indices have been used to explain inter-annual variations in the breeding performance of tropical seabirds. The El Niño Southern Oscillation (ENSO) is an atmosphere-ocean phenomenon occurring roughly every 3 to $7 \mathrm{yr}$, with its main centre of action in the tropical Pacific Ocean, but with effects much farther 
afield. ENSO events are known to affect marine food stocks throughout the tropics, and its index, the Multivariate El Niño Index (MEI), has been used to explain year-to-year fluctuations in productivity of tropical seabird species in the Pacific and Indian Oceans (Ramos et al. 2002, 2005, 2006, Vargas et al. 2006). Inter-annual climate variability in the Indian Ocean is also influenced by the Indian Ocean Dipole (IOD), which can cause anomalous sea surface temperatures (SST), winds and precipitations in some years (Saji et al. 1999). To date, however, the IOD and its index, the Dipole Mode Index (DMI), have not been invoked to explain annual changes in the breeding performance of tropical seabird species breeding in the Indian Ocean.

Measurements of the chlorophyll a concentration (CC) in surface waters provide an indicator of the standing stock of phytoplankton, which reflects primary productivity. The spatial variations in $\mathrm{CC}$ in the western Indian Ocean are the product of a number of factors: the higher nutrient content of Arabian Sea Waters, the upwelling of deeper waters near the coast, and the later development of stably stratified conditions keeping the phytoplankton in the photic zone. These various mechanisms for augmenting the nutrient content of near-surface waters are important because they help stimulate greater primary productivity, which supports the food webs leading to higher trophic levels. Large inter-annual variations in zooplankton abundance have been noted around the Seychelles, western Indian Ocean (Gallienne \& Smythe-Wright 2005), although insufficient data exist to relate this to inter-annual changes in the physical forcing. Satelliteborne sensors such as the Sea-viewing Wide Fieldof-view Sensor (SeaWiFS) can give a reasonable record of primary productivity, although they only 'see' the $\mathrm{CC}$ in the top $10 \mathrm{~m}$ or so of the water column. Phytoplankton forms the bottom of the oceanic food chain and their abundance is directly related to that of seabird prey, usually pelagic schooling fish, at higher trophic levels (Aebischer et al. 1990, Piontkovki \& Williams 1995, Platt et al. 2003). Recently, satellitebased CC data have been successfully used to explain foraging strategies and spatial distribution of tropical seabirds during the breeding season (Baduini \& Hyrenbach 2003) and their timing of breeding (Jaquemet et al. 2007). However, CC has not been used to explain temporal variations in tropical seabird productivity and other reproductive parameters indicative of timing and breeding effort.

Aride $\left(4^{\circ} 10^{\prime} \mathrm{S}, 55^{\circ} 40^{\prime} \mathrm{E}\right)$, a small island in the Central Seychelles, is a common breeding ground for many seabird species (Bowler et al. 2002), including the roseate tern Sterna dougallii. During the breeding season (May to July), roseate terns feed mainly on goat- fishes (Mullidae), which are plankton feeders during their larval stage (Krajewski \& Bonaldo 2006), and benefit greatly from the presence of schools of tuna that force their prey to the near-surface waters (Ramos 2000). Although roseate terns can migrate large distances seasonally, they forage in the direct vicinity of the colonies within a foraging radius that should not exceed $50 \mathrm{~km}$ when breeding and rearing young (Surman \& Wooler 2003), and so require plentiful food supply within that range.

In this paper, we used 8 yr of data (1998 to 2005) to study the effects of annual changes in oceanic primary productivity and other ocean indices on the breeding performance of roseate terns on Aride. Productivity (number of chicks fledged per breeding pair) and other breeding parameters (timing of laying, clutch size, egg size) were monitored annually to study year-to-year variations. We investigated in particular whether (1) annual variations in roseate tern productivity could be predicted from CC recorded in the vicinity of Aride Island during the breeding season (May to July), (2) oceanic conditions at various scales (ranging from local SST to the basin scales of the IOD and ENSO) would be more or less efficient than local CC data at predicting colony productivity, and (3) inter-annual variations in CC would explain other breeding parameters (clutch size, egg volume). We hypothesized that years with higher oceanic productivity should be reflected in higher reproductive success and positively affect other reproductive parameters such as clutch size and/or egg volume. According to life history theory, adults should time their laying season to have young in the nest when food is most abundant, thereby maximizing the number of offspring produced (Perrins 1970, Pettifor et al. 1988). Assuming that the main phytoplankton bloom represents the period of maximum food availability we predicted that roseate terns should adjust their laying date to track inter-annual changes in the timing of the chlorophyll peak. By addressing these points, we sought to explore the adaptive response of a tropical seabird species to temporal changes of food abundance in its nearby oceanic environment.

\section{MATERIALS AND METHODS}

Oceanography of the study area. Strong easterly winds exist to the south of the equator and are more intense and located slightly farther north during July than in January (Schott \& McCreary 2001). These trade winds lead to a westward-flowing South Equatorial Current (SEC) in the broad latitude range of 10 to $20^{\circ} \mathrm{S}$ (Fig. 1). Upon reaching Madagascar, part of the flow is forced north as the North Madagascar Current (NMC), 
which, on reaching the northern tip of the island, continues westward to the coast of mainland Africa. There it bifurcates, with the southern portion looping anticlockwise within the northern end of the Mozambique Channel, and the northern part feeding into the East African Coastal Current (EACC). The flow to the north of the equator shows significant seasonality due to the influence of the reversing monsoonal winds. The most pronounced changes in currents are in the direction of the Somali Current and the latitude of the eastwardflowing South Equatorial Countercurrent (SECC; Fig. 1a,b).
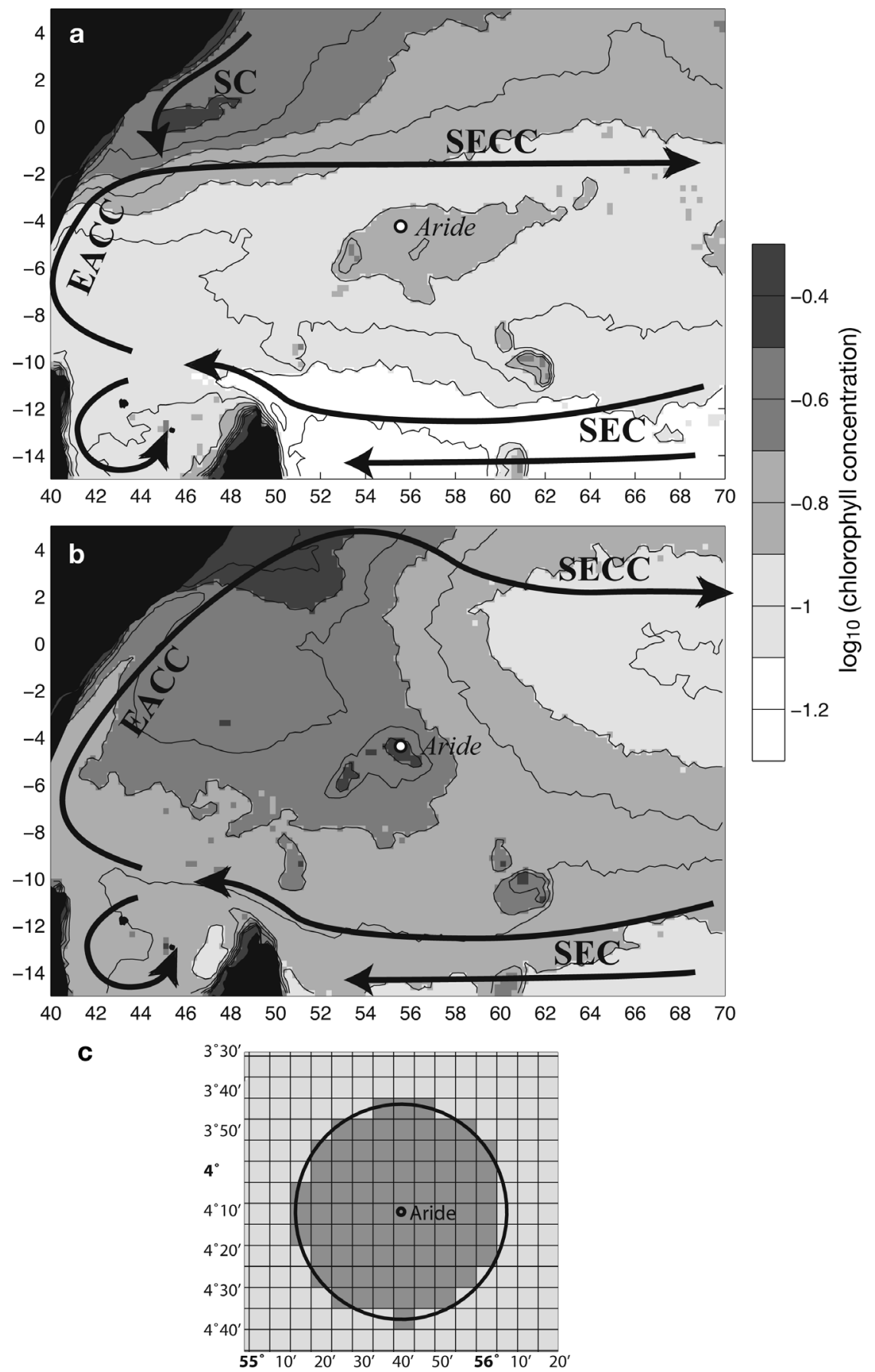

Fig. 1. Seasonal variation of Sea-viewing Wide Field-of-view Sensor (SeaWiFS)-derived chlorophyll concentration (averaged over 1998 to 2005), with schematic of main currents overlaid. SEC = South Equatorial Current, EACC = East African Coastal Current, $\mathrm{SC}=$ Somali Current, SECC = South Equatorial Countercurrent. (a) January-February, (b) July-August, (c) detail of SeaWiFS data grid showing those pixels whose centres are within $50 \mathrm{~km}$ of Aride 
There is also a marked seasonal change in the wind stress curl (WSC, Schott \& McCreary 2001). Around Aride $\left(4^{\circ} 10^{\prime} \mathrm{S}, 55^{\circ} 40^{\prime} \mathrm{E}\right)$ the WSC is positive at the start of the year, implying a net convergence of the Ekman transport and, thus, downwelling near the island; by April the WSC has changed sign and the resulting divergence leads to upwelling. This raises the thermocline locally during April to November and brings more nutrients into the near-surface waters of the photic zone.

The spatial variations in CC are shown in Fig. 1a,b. Of particular interest in this paper (given the relatively short foraging radius of the terns) is the local CC maximum around $5^{\circ} \mathrm{S}$. The eastward-flowing SECC brings nutrient rich Arabian Sea water to the area, whilst the SEC acts as a barrier to prevent the nutrients permeating farther south. The shoaling of isopycnals across the SEC also allows the deeper nutrients of the south Indian Ocean to migrate to shallower depths (New et al. 2005). In addition, the presence of the Mascarene Plateau leads to enhanced vertical mixing (New et al. 2007). Added to all this is the seasonal movement of the shallow thermocline in response to the WSC changes alluded to previously.

Inter-annual variability in the Indian Ocean. The monsoon causes strong seasonal changes, at least north of $10^{\circ} \mathrm{S}$ (Schott \& McCreary 2001), whilst the most pronounced inter-annual variations are described by 2 large-scale phenomena: ENSO and IOD (Schott \& McCreary 2001, Yu et al. 2005). The effects of ENSO in the tropical Indian Ocean may be caused by changes to the intensity and position of the atmospheric Walker circulation, or by sea level via the Indonesian throughflow, leading to the creation of westward-propagating Rossby waves. Xie et al. (2002) show how sea level changes in Indonesia in November and December can generate downwelling waves that reach the longitude of Aride roughly 7 mo later. The IOD is characterised by a difference in SST between the western and eastern areas of the equatorial Indian Ocean. The change in SST affects the wind field, producing easterly anomalies along the equator (particularly during September to November) and causing moisture convergence and enhanced precipitation in the western equatorial Indian Ocean (Saji et al. 1999). These atmospheric changes act to support the already existing SST dipole. The change in wind field leads to a reduction in the WSC and a consequent increase in sea surface height just south of the equator (Webster et al. 1999).

The effects of ENSO and IOD are inter-related, with ENSO signals in the Indian Ocean being stronger if coinciding with a positive IOD phase. Baquero-Bernal et al. (2002) suggested that many findings attributed to IOD were due to imperfect statistical analyses. In a recent paper, Yu et al. (2005) attempt to disentangle the 2 phenomena using partial correlations. They ascribe the reduction and reversal of equatorial winds in the east as part of IOD; however, in their analysis, neither phenomenon shows a significant impact in the region of the Seychelles.

Roseate tern productivity and breeding parameters. The breeding biology of the roseate tern was studied between 1998 and 2005 (8 yr) in 2 long-established colonies located on Aride Island, where 600 to 1200 pairs breed annually during May to July under a canopy of Mapou Pisonia grandis trees (Ramos et al. 2002). The number of nests was counted annually by a team of observers traversing the whole nesting area in marked sections $18 \mathrm{~d}$ after the first egg was laid (Ramos et al. 2002). Clutch size was recorded for each nest as either 1 or 2 eggs per clutch to provide an overall mean value for the breeding population. Throughout the season, data on specific breeding parameters were collected daily in 2 study quadrats established with corner posts and string within the colonies (Ramos et al. 2002). Additional data from nests observed every 1 to $3 \mathrm{~d}$ from a permanent hide were also added to increase sample sizes. Overall, the total number of nests monitored annually varied between a low of 50 (in 2000) and a high of 183 (in 2002).

During incubation we measured egg length $(\mathrm{L}, \mathrm{cm})$ and breadth $(\mathrm{B}, \mathrm{cm})$ with calipers to the nearest $0.1 \mathrm{~mm}$, calculated the volume $\left(\mathrm{V}, \mathrm{cm}^{3}=0.512 \times \mathrm{L} \times \mathrm{B}^{2}\right)$ and recorded hatching dates during daily visits of up to 45 min to the colonies. In most years, laying dates were calculated from hatching dates by subtracting an incubation period of 22 d (Gochfeld et al. 1998), except in 1999, a year with a virtually complete hatching failure, when we used exact laying dates recorded for nests viewed from the permanent hide. We used only laying dates and egg volumes from first-hatched chicks ( $a$ chicks) during data analyses. Hatching order ( $a$ - or $b$ chick) and hatchling mass were recorded at marked nests and chicks were ringed to allow subsequent recapture during the rearing period. Mass measurements were subsequently obtained from those chicks whenever encountered during daily visits to the study quadrats, which lasted throughout the season. Most surviving chicks were monitored until they fledged (25 to $35 \mathrm{~d}$ old; Milton et al. 1996, Gochfeld et al. 1998) or until they could no longer be observed. This latter situation happened generally around 2 to $3 \mathrm{wk}$ posthatching (i.e. 15 to $20 \mathrm{~d}$ old), when large chicks frequently wandered out of the nesting territory to hide under nearby rocks or herbaceous cover. Chicks with positive mass increments during the linear growth period (4 to $14 \mathrm{~d}$ old) were considered to have fledged within the usual period reported for the species, provided that food conditions did not deteriorate shortly (about $2 \mathrm{wk}$ ) after they were last encountered. Colony 
productivity (number of chicks fledged per breeding pair) was estimated annually as the mean clutch size $\times$ hatching success (probability of eggs hatched) $\times$ fledging success (probability of chicks fledged from hatched eggs).

Measurements of $\mathbf{C C}$ and ocean indices. To characterise the conditions close to Aride, we noted the local $\mathrm{SST}$ and $\mathrm{CC}$ values within a $50 \mathrm{~km}$ radius around the island, and to record climatic conditions on a larger scale, we used well-established indices of IOD (regional scale of Indian Ocean) and ENSO (large scale of Indian and Pacific Oceans). The details of these 4 measures are described here.

SST values were extracted from an optimal interpolation analysis based on in situ and satellite measurements (Reynolds et al. 2002). The dataset (ingrid.ldeo.columbia.edu/SOURCES/.IGOSS) is produced weekly on a $1^{\circ}$ grid, so only the pixel containing Aride is of interest. To investigate some of the correlations discussed in the results section, we also accessed monthly $1^{\circ}$ resolution records of wind speed and wind stress curl from a blended model observations dataset held by NOAA (las.pfeg.noaa.gov/las6_5/servlets/ dataset?catitem=48).

Satellite observations of ocean colour can be used to infer the CC of surface waters. A potential problem is that changes in community composition may change the quantities of chlorophyll recorded without corresponding to an actual increase in the mass of phytoplankton present. However, using a hydrographic section terminating at the Seychelles, Zubkov \& Quartly (2003) showed that in this region there is a strong correlation between satellite estimates of $\mathrm{CC}$ and the abundance of both eukaryotic algae and heterotrophic bacteria. Hence, year-to-year changes in satellite data are likely to reflect real variations in phytoplankton biomass. We used the data recorded by the SeaWiFS instrument, which has been providing data since September 1997. We acquired daily version 5 data from the NASA Goddard Space Flight Center on a regular grid of $0.0879^{\circ}$ in longitude and latitude; 82 such pixels lie within the terns' maximum foraging radius $(50 \mathrm{~km})$ from Aride (Fig. 1c). Because of cloud cover and a limited swath width of the instrument, there is not complete coverage on every day. We therefore formed composites corresponding to each fifth of a month. For each pixel, the 5 or $6 \mathrm{~d}$ of data were combined by taking the arithmetic mean of the logarithms of the CC $\left(\log _{10} \mathrm{CC}\right.$ in $\left.\mathrm{mg} \mathrm{m}^{-3}\right)$, as this measure is more robust to occasional extreme values (Quartly \& Srokosz 2004). We then considered the 82 pixels nearest Aride and calculated the 90th percentile, as this provides a robust estimate of the peak productivity within this radius. This assumes that the birds optimise their feeding strategy to spend most of their time over the most pro- ductive waters. As most roseate terns on Aride forage within sight of the island (Ramos 2000), we also considered measures within smaller scales (9 and $25 \mathrm{~km}$ around Aride). However, the sample sizes were smaller and the derived values were highly correlated with the values for $50 \mathrm{~km}$ (Pearson $\mathrm{r}_{50 \text { vs } 9}=0.66, \mathrm{p}<$ 0.001, $\mathrm{n}=389$; Pearson $\mathrm{r}_{50 \text { vs } 25}=0.73, \mathrm{p}<0.001, \mathrm{n}=$ $425)$; therefore, all analyses reported here are for the $50 \mathrm{~km}$ radius.

We characterised the phase of ENSO by using the MEI, which integrates 6 physical components measured over the Pacific Ocean between $30^{\circ} \mathrm{N}$ and $30^{\circ} \mathrm{S}$ : sea level pressure, zonal and meridional components of the surface wind, SST, air temperature and cloudiness. We obtained bimonthly values of the MEI (www. cdc.noaa.gov/people/klaus.wolter/MEI/table.html) for each of 12 overlapping periods (e.g. Dec/Jan, Jan/Feb, Feb/Mar). Positive values of the MEI indicate the El Niño phase, while negative values represent the cold El Niño phase, i.e. La Niña (Wolter \& Timlin 1993). For the IOD, we used the DMI (monthly values) recommended by S. A. Rao of the Frontier Research Center for Global Change, Japan (www.jamstec.go.jp/frsgc/ research/d1/iod/). A positive DMI is associated with higher SST in the west and lower SST in the east (Saji et al. 1999).

Data analyses. Phytoplankton bloom, ocean indices and reproductive parameters: Analyses of variance (1-way ANOVA) were performed to study inter-annual variations in reproductive parameters (laying date, egg volume), followed by Neuman-Keuls multiple comparison tests. Pearson product-moment correlations were used to check for a linear association with environmental factors whenever appropriate (Zar 1999). To investigate the effect of inter-annual variations in chlorophyll abundance on roseate tern productivity, we used 3 measures for each year: (1) $\log _{10} \mathrm{CC}$ May to July: the mean $\log _{10} \mathrm{CC}$ value over the roseate tern breeding period obtained by averaging the 6-d composites over May, June and July; (2) $\log _{10} \mathrm{CC}$ peak: the peak $\log _{10} \mathrm{CC}$ value of the $6 \mathrm{~d}$ composites during the May to August bloom; and (3) $\log _{10} \mathrm{CC}$ rate of increase: the rate of increase of $\log _{10} \mathrm{CC}$ during the roseate tern breeding period, defined as the slope of the regression line from the birds' mean laying date to the date of $\log _{10} \mathrm{CC}$ peak value. For years with 2 dates of $\log _{10} \mathrm{CC}$ peak, we used the mid-point date to perform the regression. Differences between significant slopes were tested using a Tukey's multiple comparison test (Zar 1999).We used these 3 chlorophyll abundance variables and mean May to July values of MEI, DMI and SST to model annual roseate tern productivity using simple linear regressions. To further investigate the mechanisms by which ocean productivity around Aride may affect breeding roseate terns, clutch 
size and egg volume were also used as dependent variables.

A multiple regression analysis was performed to predict variations in productivity and clutch size, but due to the relatively small number of years spanned by this study ( $\mathrm{n}=8 \mathrm{yr}$ ), we restricted our models to 4 predictors: the 3 ocean indices (MEI, DMI and SST) and the $\mathrm{CC}$ variable with the highest explanatory power in the univariate analysis. A stepwise selection of predictors was avoided in favour of a full model approach (i.e. a model containing all 4 predictors) since the former procedure could result in biased parameter estimation (Whittingham et al. 2006). The multiple regression was performed on standardized predictors (mean $=0, \mathrm{SD}=$ 1) to understand their relative contribution in the prediction of the dependent variable (beta coefficients; Zar 1999).

Phytoplankton bloom and timing of breeding: We correlated monthly DMI, MEI and SST means in May and June with mean laying date. The weekly SST time series showed a consistent decrease between May and mid-June during each of the 8 yr spanned by this study (all regression $r<0.01$ ), so the slope of the regression line fitting this decrease was calculated for each year and used as a variable to check for a correlation with laying date. We compared also the mean rate of decrease in SST between years of early (18 to 28 May) and late (after 28 May) egg laying using a $t$-test. Records of laying dates were also used to quantify variations in the timing of breeding of roseate terns in relation to the timing and duration of the main phytoplankton bloom. For each roseate tern nest monitored, we calculated a 'peak-bloom lag' value as the difference (in number of days) between the laying date (a-egg) and the date of $\log _{10} \mathrm{CC}$ peak for that year. Mean peakbloom lag values were compared between years using ANOVA.

A linear modeling approach was used to further assess the predictive effect of the peak bloom lag variable on roseate tern productivity. Since most of the fluctuation in productivity on Aride is shaped by the probability of successfully raising a single chick (a-chick), with the fledging success of $b$-chicks being usually close to zero (Ramos et al. 2002), we developed a logistic regression model (binomial logit-linear) with the success of $a$ chicks $(0=$ not fledged, $1=$ fledged; $\mathrm{n}=511$ ) as the dependent variable. For each nest monitored during the 6 yr of non-zero productivity spanned by this study (1998 and 2001 to 2005), peak-bloom lag and other biologically significant predictors such as laying date, clutch size and egg volume were included in the model. Except for clutch size, observations were divided for each predictor into quartiles of the distribution with the estimate (slope) for the first (lower) quartile (reference level) set to 0 , while those of the remaining quartiles were allowed to vary (Hosmer \& Lemeshow 2000). This method was justified because the probability of fledging a chick was not considered to be necessarily linear among quartiles.

The relative contribution of each variable to fledging success was assessed using odds ratios (OR) comparing for each quartile the probability of successfully raising a chick with the reference level (first quartile). Significant differences were assessed with Wald $\chi^{2}$ tests and $95 \%$ Wald's confidence limits for each odds ratio (Hosmer \& Lemeshow 2000). When the confidence limits span the value of 1 , this indicates that there is no significant difference between the odds of successfully raising a chick at the level considered and the reference level. We checked model fitness with the Hosmer-Lemeshow goodness-of-fit statistic ( $\chi^{2}$ test) and the area under the receiver operating characteristic (ROC) curve (Hosmer \& Lemeshow 2000). The area under the ROC curve ranges from 0 to 1 and as a general rule, a ROC $\sim 0.7,0.8$ or 0.9 suggests acceptable, excellent or outstanding discrimination, respectively (Hosmer \& Lemeshow 2000). Data were analysed using the SPSS statistical package, release 13.0.

\section{RESULTS}

\section{Year-to-year variations in breeding performance}

Complete breeding failures were recorded in 1999 and 2000 due to chick starvation and nest abandon-

Table 1. Sterna dougallii. Comparison of breeding parameters and productivity (no. chicks fledged per breeding pair) of the roseate tern population on Aride Island, Seychelles, from 1998 to 2005. Values are presented as mean \pm SD except for clutch size (sample sizes in parentheses). Superscripts following values within a column having at least one letter in common indicate no significant difference (Neuman-Keuls test, $\mathrm{p}>0.05)$. nd = no data

\begin{tabular}{|cclll|}
\hline Year & \multicolumn{1}{c}{ Laying date } & $\begin{array}{c}\text { Clutch } \\
\text { size }\end{array}$ & $\begin{array}{c}\text { Egg volume } \\
\left(\mathrm{cm}^{3}\right)\end{array}$ & Productivity \\
\hline 1998 & 30 May $\pm 6 \mathrm{~d}(152)^{\mathrm{C}}$ & $1.27(962)$ & $17.6 \pm 1.4(132)^{\mathrm{B}, \mathrm{C}}$ & $0.55(132)$ \\
1999 & 20 Jun $\pm 3 \mathrm{~d}(104)^{\mathrm{F}}$ & $1.16(1112)$ & $17.5 \pm 1.3(58)^{\mathrm{B}, \mathrm{C}}$ & $0.00(58)$ \\
2000 & 11 Jun $\pm 4 \mathrm{~d}(50)^{\mathrm{E}}$ & $1.03(607)$ & \multicolumn{1}{c}{ nd } & $0.02(50)$ \\
2001 & 26 May $\pm 6 \mathrm{~d}(68)^{\mathrm{B}}$ & $1.13(733)$ & $18.3 \pm 1.3(54)^{\mathrm{A}}$ & $0.21(140)$ \\
2002 & 27 May $\pm 10 \mathrm{~d}(183)^{\mathrm{B}}$ & $1.11(1046)$ & $17.7 \pm 1.4(154)^{\mathrm{B}, \mathrm{D}}$ & $0.53(214)$ \\
2003 & $9 \mathrm{Jun} \pm 3 \mathrm{~d}(69)^{\mathrm{D}}$ & $1.33(705)$ & $17.9 \pm 1.4(65)^{\mathrm{A}, \mathrm{C}, \mathrm{D}}$ & $0.47(119)$ \\
2004 & $18 \mathrm{May} \pm 4 \mathrm{~d}(75)^{\mathrm{A}}$ & $1.42(528)$ & $17.9 \pm 1.5(60)^{\mathrm{A}, \mathrm{C}, \mathrm{D}}$ & $0.57(122)$ \\
2005 & $28 \mathrm{May} \pm 6 \mathrm{~d}(53)^{\mathrm{B}}$ & $1.06(686)$ & $17.2 \pm 1.4(46)^{\mathrm{B}}$ & $0.35(96)$ \\
& & & & \\
\hline
\end{tabular}




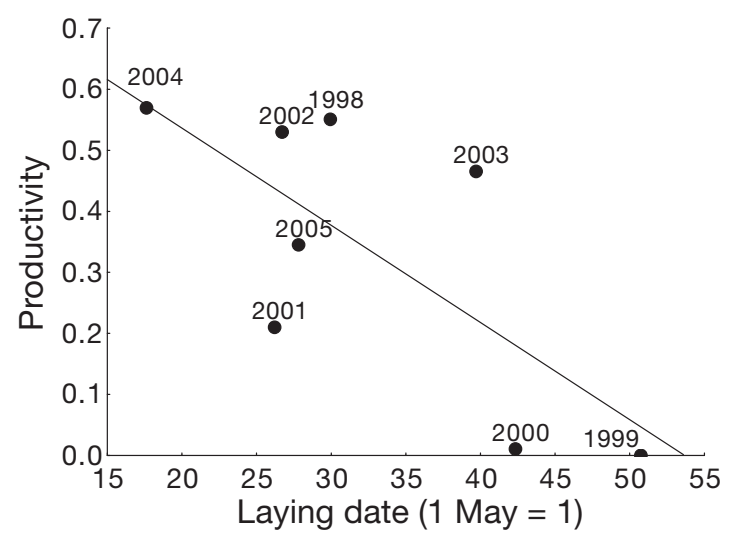

Fig. 2. Sterna dougallii. Pearson product-moment correlation between colony productivity (no. of chicks fledged per pair) and laying date (day number beginning 1 May) for the period from 1998 to $2005(\mathrm{r}=-0.72, \mathrm{p}=0.04)$

ment by parents (fledging success $=0$ ), whereas productivity was low in 2001 and 2005, with few a-chicks fledging (but no $b$-chicks) in those years (Table 1). During the remaining $4 \mathrm{yr}$, fledging success of a-chicks increased, but that of $b$-chicks remained very low (0.01 in 2002, 0.06 in 1998 and 2003, and 0.11 in 2004), resulting in an average productivity of ca. 0.5 chicks per breeding pair (Table 1). Clutch size ranged from
1.03 and 1.06 eggs per clutch in 2000 and 2005, respectively, to 1.42 in 2004 (Table 1). Overall, differences in mean egg volumes were slight, with those laid in 2005 being on average $6 \%$ smaller than those in 2001 (1-way ANOVA: $F_{6,562}=3.44, \mathrm{p}<0.001$ ). There was also a negative correlation between laying date and productivity (Fig. 2).

\section{CC, ocean indices and breeding performance}

Chlorophyll abundance. The 8 yr of SeaWiFS data showed that the waters around Aride experienced 2 seasonal blooms in phytoplankton productivity (Fig. 3a,b). The first, a moderate phytoplankton bloom, occurred between December and February (austral summer), with the main bloom between May and August (austral winter) overlapping with the roseate tern breeding season (May to July).

The May to August phytoplankton bloom varied from yr to yr in the date of the annual maximum (Fig. 4), with values ranging from 22 June in 2000 (Day 174) and 2002 (Day 173), to 16 August in 1999 and 2003 (Day 228). There were also variations in amplitude and rate of increase (Table 2, Fig. 4). Among the most important features were the weak annual CC peak values observed in 1999 and 2000, when breeding success was

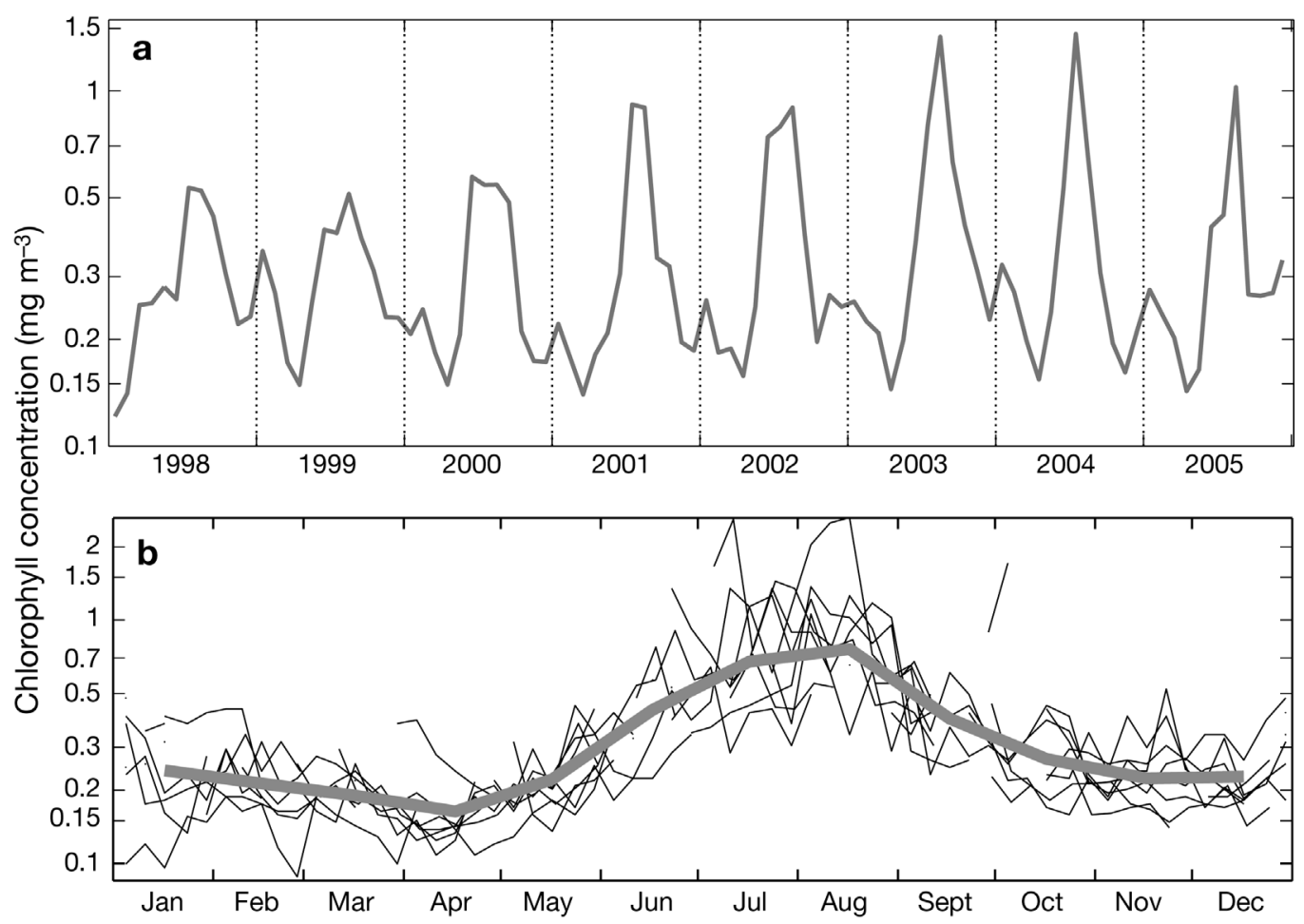

Fig. 3. (a) Monthly mean chlorophyll concentrations within $50 \mathrm{~km}$ radius around Aride Island. Monthly data plotted from January 1998 to December 2005, but labelled every 2 mo. (b) Thin lines show chlorophyll records for each of the 8 yr at fifth of a month resolution and the thick grey line gives the monthly averages 
virtually zero, contrasting with the peaks of 2003 and 2004, when roseate tern productivity reached the highest values (Fig. 4). In the poorest years, the rate of increase (slope) of the $\mathrm{CC}$ during the breeding season was virtually zero (1999 and 2000, Table 2), whereas the largest slope was in 2004, suggesting the most favourable conditions existed in that year (Table 2, Fig. 4).
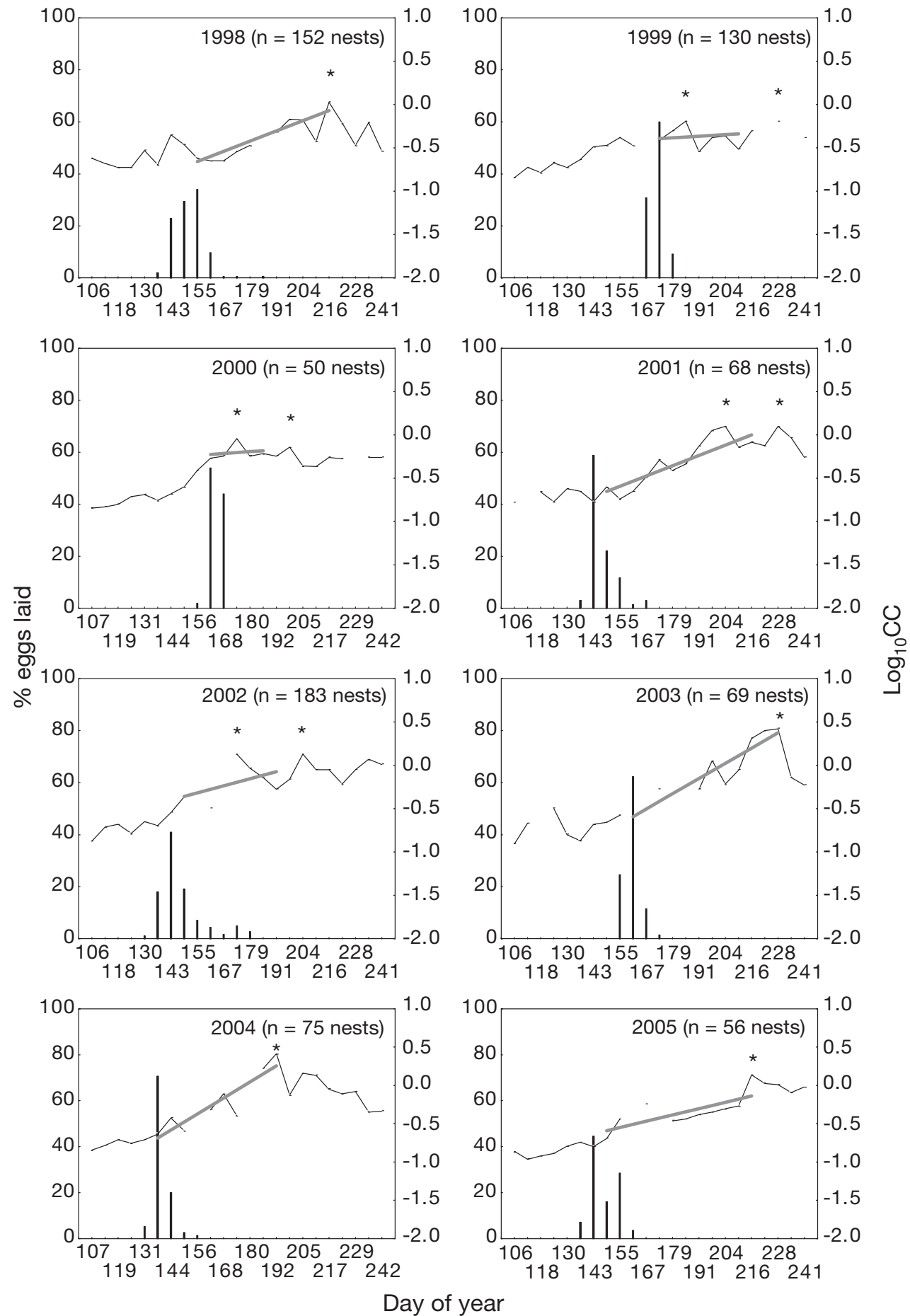

Fig. 4. Sterna dougallii. Annual distribution of egg laying dates (left axis) and $\log _{10} \mathrm{CC}$ (chlorophyll concentration) within $50 \mathrm{~km}$ radius around Aride Island plotted from mid-April to end of August (right axis). The grey line represents the linear regression of $\log _{10} \mathrm{CC}$ values starting from mean laying date (Table 1) to the date of $\log _{10} \mathrm{CC}$ peak value during the May to August bloom (*). In years with 2 dates of $\log _{10} \mathrm{CC}$ peak, the regression was performed using the mid-point between these 2 dates 
Table 2. Ocean indices (MEI = Multivariate El Niño Index, DMI = Dipole Mode Index), sea surface temperature (SST) and variables derived from time series of chlorophyll concentration ( $\log _{10} \mathrm{CC}$ ) around Aride (1998 to 2005) during the main annual phytoplankton bloom coinciding with the roseate tern breeding season. $\log _{10} \mathrm{CC}$ rate of increase per day and mean peak-bloom lag were compared between years. Superscripts following values within a column having at least one letter in common indicate no significant difference between years (Multiple comparison test, $\mathrm{p}>0.05$ )

\begin{tabular}{|c|c|c|c|c|c|c|c|}
\hline Year & MEI & DMI & $\operatorname{SST}\left({ }^{\circ} \mathrm{C}\right)$ & $\begin{array}{l}\log _{10} \mathrm{CC} \\
\text { May to Jul } \\
\left.(\mathrm{mg} \mathrm{m})^{-3}\right)\end{array}$ & \multicolumn{2}{|c|}{$\begin{array}{c}\log _{10} \mathrm{CC} \text { rate of increase } \\
\text { per day }(\mathrm{n}) \text { and } \\
\text { associated p value }\end{array}$} & $\begin{array}{c}\text { Mean peak-bloom } \\
\operatorname{lag}(\text { no. of days } \\
\pm \mathrm{SD})^{\mathrm{b}}\end{array}$ \\
\hline 1998 & 1.158 & -0.347 & 27.98 & -0.471 & $0.059^{\mathrm{A}, \mathrm{B}}(10)$ & $<0.01$ & $65.9 \pm 6.4^{\mathrm{E}}$ \\
\hline 1999 & -0.522 & -0.326 & 27.29 & -0.463 & $0.009(9)$ & 0.59 & $56.4 \pm 2.6^{\mathrm{D}}$ \\
\hline 2000 & -0.158 & -0.075 & 27.40 & -0.397 & $0.011(5)$ & 0.77 & $10.7 \pm 3.7^{\mathrm{A}}$ \\
\hline 2001 & 0.100 & -0.363 & 27.34 & -0.411 & $0.059^{\mathrm{A}, \mathrm{B}}(14)$ & $<0.01$ & $70.7 \pm 5.2^{\mathrm{F}}$ \\
\hline 2002 & 0.757 & -0.472 & 26.88 & -0.279 & $0.041^{\mathrm{B}}(8)$ & 0.03 & $41.9 \pm 10.5^{\mathrm{B}}$ \\
\hline 2003 & 0.018 & 0.388 & 27.70 & -0.407 & $0.088^{\mathrm{A}, \mathrm{B}}(8)$ & $<0.01$ & $68.4 \pm 3.3^{\mathrm{E}, \mathrm{F}}$ \\
\hline 2004 & 0.389 & -0.515 & 27.04 & 0.246 & $0.105^{\mathrm{A}}(8)$ & $<0.01$ & $53.2 \pm 3.4^{\mathrm{C}}$ \\
\hline 2005 & 0.536 & -0.275 & 28.00 & -0.505 & $0.041^{\mathrm{B}}(10)$ & $<0.01$ & $68.3 \pm 6.3^{\mathrm{E}, \mathrm{F}}$ \\
\hline \multicolumn{8}{|c|}{$\begin{array}{l}{ }^{a} \log _{10} \mathrm{CC} \text { rate of increase is the linear regression coefficient of } \log _{10} \mathrm{CC} 6 \text { - } \mathrm{d} \text { composites taken from mean laying date (Table } 1 \text { ) } \\
\text { to the date of annual CC peak (Fig.4); } 1999 \text { and } 2000 \text { not included in the multiple comparison test }\end{array}$} \\
\hline \multicolumn{8}{|c|}{ 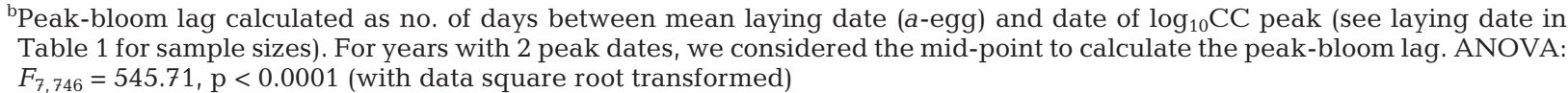 } \\
\hline
\end{tabular}

Regression model. Both the annual CC peak value and the rate of increase of CC during the phytoplankton bloom were correlated (Pearson $\mathrm{r}=0.91, \mathrm{p}=0.001$, $\mathrm{n}=8 \mathrm{yr}$ ) and explained, respectively, 51\% (simple regression: $\left.F_{1,6}=6.3, \mathrm{p}=0.045\right)$ and $60 \%\left(F_{1,6}=9.0, \mathrm{p}=\right.$ 0.023 ; Table 3 ) of the inter-annual variation in roseate tern productivity. The rate of increase in $\mathrm{CC}$ was the only explanatory variable that positively influenced clutch size $\left(F_{1,6}=14.3, p=0.009\right.$; Table 3, Fig. 5$)$, but no such association (response) was found with egg volume $\left(F_{1,5}=1.7, \mathrm{p}=0.23\right)$.

The yearly mean CC for May through July was negatively correlated with local SST averaged over the same period (Pearson $r=-0.83, p=0.01, n=8$ ), but no other correlations were found between ocean indices (Table 2). The mean CC and SST averaged over the May to July period did not predict roseate tern productivity. The MEI during May to July explained $64 \%$ of the variation in roseate tern productivity (simple regression: $F_{1,6}=10.7, \mathrm{p}=$ 0.016), but there was no significant relationship with the DMI (Table 3). Together, the MEI and the rate of increase in $\mathrm{CC}$ explained more than $90 \%$ of the variation in roseate tern productivity (multiple regression: $F_{4,3}=$ 13.1, $\mathrm{p}=0.03$, with MEI coefficient $( \pm \mathrm{SE})=0.76 \pm 0.19, \mathrm{p}=0.03$, and $\mathrm{CC}$ coefficient $=0.48 \pm 0.16, p=0.05$ ).

\section{Duration of the CC bloom, ocean indices and timing of breeding}

Inter-year variation. Mean laying date of roseate terns varied among years (1-way ANOVA $F_{7,746}=$ 230.05, p < 0.001). The birds laid on average $1 \mathrm{mo}$ earlier in 2004 compared with 1999 (18 May vs. 20 June) and during half of the years spanned by this study, egg-laying occurred within the same week (26 to 30 May; Table 1). The mean peak-bloom lag was ca. 2 mo (53 to $71 \mathrm{~d}$ ) during 6 of the 8 yr studied (Table 2, Fig. 4). Mean laying dates compared among the same 6 yr differed by ca. 1 mo (18 May in 2004 to 20 June in 1999, Table 1), suggesting that roseate terns adjusted

Table 3. Sterna dougallii. Percentages of variation in annual mean clutch size (no. of eggs per clutch) and productivity (chicks fledged per pair) explained by selected environmental variables between 1998 and 2005 (Simple regression models with $\mathrm{df}=1$ and $6, \mathrm{n}=8 \mathrm{yr}$ ); CC: chlorophyll concentration, MEI: Multivariate El Niño Index, DMI: Dipole Mode Index, SST: sea surface temperature

\begin{tabular}{|c|c|c|c|c|c|c|}
\hline \multirow[t]{2}{*}{ Covariate } & \multicolumn{3}{|c|}{ Clutch size } & \multicolumn{3}{|c|}{ Productivity } \\
\hline & $\begin{array}{l}\mathrm{R}^{2} \\
(\%)\end{array}$ & $\begin{array}{c}\text { Regression } \\
\text { coefficient } \pm \text { SE }\end{array}$ & $\mathrm{p}$ & $\begin{array}{l}\mathrm{R}^{2} \\
(\%)\end{array}$ & $\begin{array}{c}\text { Regression } \\
\text { coefficient } \pm \text { SE }\end{array}$ & $\mathrm{p}$ \\
\hline $\begin{array}{l}\log _{10} \mathrm{CC} \text { rate of } \\
\text { increase }\end{array}$ & 65.5 & $3.11 \pm 0.82$ & 0.009 & 60.0 & $5.41 \pm 1.80$ & 0.023 \\
\hline $\log _{10} \mathrm{CC}$ peak & 34.3 & - & 0.074 & 51.3 & $0.72 \pm 0.28$ & 0.045 \\
\hline $\log _{10}$ CC May-Jul & 12.0 & - & 0.401 & 18.0 & - & 0.295 \\
\hline MEI (May-Jul) & 3.9 & - & 0.638 & 64.1 & $0.35 \pm 0.11$ & 0.016 \\
\hline DMI (May-Jul) & 1.1 & - & 0.803 & 1.6 & - & 0.763 \\
\hline SST (May-Jul) & 0.1 & - & 0.981 & 0.2 & - & 0.919 \\
\hline
\end{tabular}


between May and August (southeast monsoon). The breeding season of most seabirds on Aride coincides with the main bloom, but some species also breed during the northwest monsoon (e.g. lesser noddy Anous tenuirostris and brown noddy A. stolidus; Bowler et al. 2002), suggesting that breeding in the tropical Indian Ocean is dictated by the seasonality of food resources (Le Corre et al. 2003).

We found year-to-year differences in the main phytoplankton bloom with respect to its average value during May to July (mean CC), peak amplitude (maximum CC), timing of the peak, and rate of increase (' $\mathrm{CC}$ growth rate') (Table 2). Both timing (Platt et al. 2003) and intensity (Robinson 2004) of the phytoplankton bloom have been related to the survival and density of phytoplankton-feeding fishes. On Aride, roseate terns feed primarily on young ( 0 yr age group) goatfishes (Mullidae; Ramos 2000), which are plankton feeders during their larval stage (Krajewski \& Bonaldo 2006). Observations of east African reef fish species suggest that adults spawn mostly in October to November and March to May (Nzioka 1979), corresponding to the onset of the phytoplankton blooms observed in this study and raising the possibility of a major recruitment during the peak of the bloom. Therefore, we speculate that the abundance of fish schools preyed upon by the birds may, at least in part, be connected to CC recorded in the surrounding waters. Such a relationship was suggested for the northern anchovy Engraulis mordax (Robinson 2004), but cannot be validated for goatfishes around Aride without direct in situ measurements of fish stocks. In particular, the observation of a lagged response between peaks of abundance at both trophic levels would be particularly helpful to support a 'bottom-up control' hypothesis (Aebisher et al. 1990), which has been demonstrated for several fish species in the Atlantic Ocean (Beaugrand et al. 2003, Platt et al. 2003, Frederiksen et al. 2006). Nevertheless, the similarities reported hereafter between various measures of $\mathrm{CC}$ and roseate tern reproductive parameters support the existence of a strong causal relationship between CC levels off Aride Island during the roseate tern breeding season and prey availability.

\section{Effects of annual changes in phytoplankton abundance}

During the roseate tern breeding season, inter-annual variations in CC (rate of increase and peak value) were correlated with productivity; in years of rapid phytoplankton growth resulting in an intense bloom, roseate terns were more successful than in years when the phytoplankton bloom was less apparent. This was particularly obvious in 1999 to 2000 when only a weak phytoplankton bloom occurred, resulting in a complete breeding failure due to chick starvation and nest abandonment by parents. In contrast, the rapid growth of the 2004 bloom, associated with the highest peak value recorded during the study, led to the most successful breeding season (highest colony productivity). Such differences may be ascribed to significant year-to-year fluctuations in the availability of prey for roseate terns, particularly young goatfishes (Mullidae) during the breeding season. In fact, tropical roseate terns feed on schooling fish made readily available in the upper layer of the water column by subsurface predators such as dolphins and tunas (Ramos 2000). Although the association between roseate terns and subsurface predators was not examined in this study, Ballance et al. (1997) showed that large flocks of boobies found over surface waters of highest CC were also those most often associated with subsurface predators. Thus, we further speculate that subsurface predators may also concentrate in oceanic areas with higher productivity that attracts zooplankton and marine fishes, thereby providing a functional link between roseate terns feeding around Aride and their main prey.

We found a significant increase in clutch size in years of higher $\mathrm{CC}$, which is consistent with previous studies suggesting that food is the primary factor affecting egg formation in larids (Sydeman et al. 1991, Suddaby \& Ratcliffe 1997). There was, however, no apparent correlation between CC fluctuations and egg size. These results are similar to those reported for common terns Sterna hirundo and roseate terns in the North Atlantic, where Safina et al. (1988) found that in years of higher food supply, terns had a tendency to lay larger clutches, but not larger eggs. This finding suggests that when food conditions are favourable, it may be more advantageous for tropical roseate terns to allocate somatic reserves to the formation of supplementary rather than larger eggs, although our data showed that the larger clutches found in 2004 also contained larger eggs (Table 1). Roseate terns may maximize clutch and egg size in relation to the prevalent food conditions at the time of egg laying, but clutch size is probably a better proxy measure reflecting food availability (CC) around Aride. Rapidly increasing food conditions encountered by females upon arrival at the breeding quarters several weeks before laying may be important cues to later plentiful food supply during the season. Females may lay as many eggs as somatic reserves allow and later regulate their breeding effort by a reduction of brood size or clutch desertion if food is scarce (Monaghan et al. 1992). This seems to be the situation on Aride where parents are usually unable to raise more than a single chick except in years of apparent highest food supply conditions (Ramos et al. 2002, this study). 


\section{Effects of laying date and timing of phytoplankton bloom}

During the 8 yr spanned by this study, a negative correlation between laying date and roseate tern productivity was observed, hence suggesting the importance of food availability in shaping breeding parameters. When environmental conditions were poor, such as in 1999 and 2000 (i.e. 2 yr of very low roseate tern productivity), birds initiated laying much later, with an overall mean laying date for the whole colony delayed by up to 1 mo compared with 2004 (i.e. year of highest colony productivity), when food supply conditions were presumably very good (greater CC peak and oceanic productivity). Because food is often seasonally declining, optimal breeding theory predicts that laying should be timed to allow a match between the chick rearing period (i.e. the period of peak food demand during breeding) and the period of maximum food availability (Perrins 1970). Thus, assuming that the peak date of the phytoplankton bloom around Aride Island reflected the period of maximum food availability, roseate terns were, on average, expected to lay at least ca. 50 to $60 \mathrm{~d}$ before this date to have a reasonable chance to fledge their chicks before food conditions started to deteriorate. This time lag (peak-bloom lag) corresponded to an incubation period of 22 to $24 \mathrm{~d}$ (Gochfeld et al. 1998) and a chick rearing period of 25 to $35 \mathrm{~d}$ (Milton et al. 1996, Gochfeld et al. 1998), and was found in 6 out of 8 yr spanned by this study (except in 2000, a poor year, and 2002). When removing the $2 \mathrm{yr}$ of poor food availability (1999 and 2000), such a strategy was found to be important in explaining fledging success on Aride. Therefore, the inter-annual variations in mean laying dates (Table 1) suggested that roseate terns may have adjusted their breeding phenology, so that in most years, the chick rearing period of the majority of birds corresponded to the maximum availability of food around Aride. Optimal adjustment in response to environmental fluctuations may, however, not always be achieved (see Safina \& Burger 1988), which may perhaps account for the mismatch observed in 2000 and 2002 (Table 2). Thus, extrinsic factors such as the peak-bloom lag and the laying date appear to be important in shaping breeding success on Aride when compared with intrinsic factors (clutch and egg size, Table 4). Overall, this pattern suggests that in years with a marked seasonal phytoplankton bloom, there is a strong selection to lay early in the season, and the lag between laying and the CC peak is adjusted by the most productive birds to match the chick rearing period with the period of maximum food availability. Conversely, in years when oceanic productivity is low or fails to show a marked seasonal bloom, terns may have difficulty with determining the appropriate time to lay eggs (e.g. 2000) and may fail completely.

Which cues roseate terns use to predict the peak in phytoplankton bloom remain to be closely investigated. In passerines, laying date is finely tuned following both photoperiod and ambient temperature, which are good indicators of when food resources will be large enough to raise chicks (Nager \& van Noordwijk 1995). In this study, we found a negative correlation between mean CC and SST around Aride during the breeding season (May to July), which is consistent with greater upwelling or mixing bringing cooler nutrientladen waters to the surface. Thus, a stronger decrease in SST from early May onwards is likely to be associated with favourable oceanic conditions earlier in the season, which may be invoked to explain the tendency for roseate terns to lay earlier in years of stronger decrease in SST from May to June. However, once there has been an injection of nutrients into the photic zone, subsequent stratified conditions allowing a warm surface may be best for encouraging phytoplankton growth. In Cassin's auklet Ptychoramphus aleuticus breeding in the Pacific Ocean, laying date is positively correlated with SST and adjusted to respond to interannual variations in oceanographic conditions affecting the availability of their main prey, namely euphausiids (Abraham \& Sydeman 2004). Jaquemet et al. (2007) previously found a match between a decrease in local SST, corresponding to locally enhanced $\mathrm{CC}$, and egg laying by sooty terns Sterna fuscata in the western Indian Ocean. Altogether, this suggests that SST may be the cue used by the birds to predict the timing of fish abundance and adjust egg laying accordingly.

\section{Effects of ocean indices}

In a previous study, Ramos et al. (2002) found a significant influence of local (SST) and large-scale (MEI) oceanographic events, respectively, on the number of roseate terns that attempt to breed and on their timing of breeding. We found that MEI during the breeding season (May to July) may also play a significant role in explaining inter-annual fluctuations in colony productivity, while we did not detect any effect of the DMI. Both the MEI and local CC explained a fairly similar fraction of the total variance observed, and overall, the combination of local CC and large-scale climatic conditions (MEI) accounted for most of the variation observed over the study period (>90\%). Our results also suggest that negative values of the MEI had a detrimental effect on roseate tern productivity. Breeding failures of brown noddies during La Niña years have been previously reported for Aride (Ramos et al. 2006). 
The IOD has its largest climatic effect during September to November (Saji et al. 1999), and little coherent atmospheric or oceanic variability can be discerned unless analysis is segregated into specific calendar months (Baquero-Bernal et al. 2002). The key times for roseate terns laying and breeding occur well before IOD has any appreciable effect. On the other hand, ENSO is a large-scale phenomenon that persists for many months, with a peak response in the tropical Indian Ocean lagging behind that in the Pacific, and consequently still having a basin-scale impact at the time of breeding and laying activity.

A possible mechanism involves the interaction of ENSO-related Rossby waves triggered off Sumatra reaching the Seychelles in the early to middle part of the year, with the associated downwelling (Xie et al. 2002) deepening the otherwise shallow nutricline found just to the north of the SEC and modifying the seasonal reduction in SST. According to this hypothesis, the effect at the Seychelles should lag the Pacificbased signals recorded by the MEI by about $7 \mathrm{mo}$; however, a repeat of our analysis using lagged MEI values explained no more of the variance than the standard correlation analysis. An alternative hypothesis is that an increase in the number or severity of storms during the La Niña phase could affect the birds' ability to forage successfully; however, an examination of monthly wind speeds showed no significant effect of ENSO on wind speeds at this location (D. Monticelli, J. A Ramos, G. D. Quartlly unpubl. data). Ramos et al. (2002) showed that daily variations in wind speed did not influence roseate tern chick provisioning on Aride. Finally, we also considered the interannual variations in WSC, which should modulate the degree of upwelling. However, the WSC for the $1^{\circ}$ pixel containing Aride showed no significant correlation with MEI or the local rate of increase of $\mathrm{CC}$.

\section{CONCLUSION}

To our knowledge, this is the first study showing that a tropical seabird species is sensitive to inter-annual variations in timing and intensity of the phytoplankton bloom around the colonies, which may be connected to year-to-year variations in the availability of prey. In particular, clutch size appears to be a sensitive reproductive parameter reflecting the food conditions prevalent in the surrounding waters. We also hypothesize that roseate tern females may rely on SST conditions early in the season to anticipate the local increase in food supply coinciding with the seasonal phytoplankton bloom, and time their egg laying accordingly. Overall, these patterns indicate that the reproduction of this top marine predator is dictated by the temporal variability in oceanographic conditions. Interestingly, this study suggests that CC data available over the world's oceans (SeaWiFS sensor) may be a useful tool to develop models predicting the fate of colonies of inshore feeding seabirds when other, more conventional monitoring methods cannot be used.

Acknowledgements. We are indebted to J. Cadbury and the Island Conservation Society for permission to work on Aride. J. Cadbury provided also financial support for traveling to Aride. Satellite chlorophyll data were produced by the SeaWiFS Project at NASA Goddard Space Flight Center and obtained from their Distributed Active Archive Center. We thank all those involved in the production and distribution of data, and L. Marsh for shepherding the data at the National Oceanography Centre. Roseate Tern data in 2000 were obtained by J. Hunter and J. Bowler. We are grateful to R. Hankin and W. A. Link for discussions on statistical analysis. D. M. also thanks D. Sirjacobs for assisting with bibliographical research. Earlier drafts of this paper benefited greatly from the comments of 4 anonymous reviewers.

\section{LITERATURE CITED}

Abraham CL, Sydeman WJ (2004) Ocean climate, euphausiids and auklet nesting: inter-annual trends and variation in phenology, diet and growth of a planktivorous seabird, Ptychoramphus aleuticus. Mar Ecol Prog Ser 274:235-250

Aebischer NJ, Coulson, JC, Colebrook JM (1990) Parallel long-term trends across four marine trophic levels and weather. Nature 347:753-755

Baduini CL, Hyrenbach KD (2003) Biogeography of procellariiform foraging strategies: Does ocean productivity influence provisioning? Mar Ornithol 31:101-112

Ballance LT, Pitman, RL, Reilly SB (1997) Seabird community structure along a productivity gradient: importance of competition and energetic constraint. Ecology 78:1502-1518

Ballance LT, Pitman, RL, Fiedler PC (2006) Oceanographic influences on seabirds and cetaceans of the eastern tropical Pacific: a review. Prog Oceanogr 69:360-390

Baquero-Bernal A, Latif M, Legutke S (2002) On dipole like variability of sea surface temperature in the tropical Indian Ocean. J Clim 15:1358-1368

Beaugrand G, Brander KM, Lindley JA, Souissi S, Reid PC (2003) Plankton effect on cod recruitment in the North Sea. Nature 426:661-664

Bowler J, Betts M, Bullock I, Ramos JA (2002) Trends in seabird numbers on Aride Island Nature Reserve, Seychelles 1988-2000. Waterbirds 25:26-38

Dunn EK (1975) The role of environmental factors in the growth of tern chicks. J Anim Ecol 44:743-754

Frederiksen M, Edwards M, Richardson AJ, Halliday NC, Wanless S (2006) From plankton to top predators: bottomup control of a marine food web across four trophic levels. J Anim Ecol 75:1259-1268

Gallienne CP, Smythe-Wright D (2005) Epipelagic mesozooplankton dynamics around the Mascarene Plateau and Basin, Southwestern Indian Ocean. Philos Trans R Soc Lond A 363:191-202

Gochfeld M, Burger J, Nisbet ICT (1998) Roseate tern (Sterna dougallii). In: Poole A, Gill F (eds) The birds of North America, no. 370. The Academy of Natural Sciences, Philadelphia, PA, and The American Ornithologists' Union, Washington, DC 
Hosmer DW, Lemeshow S (2000) Applied logistic regression, 2nd edn. Wiley Interscience, New York, NY

Jaquemet S, Le Corre M, Quartly GD (2007) Ocean control of the breeding regime of the sooty terns in the South-West Indian Ocean. Deep-Sea Res I 54:130-142

Krajewski JP, Bonaldo RM (2006) Plankton-picking by the goatfish Pseudupeneus maculatus (Mullidae), a specialized bottom forager. J Fish Biol 68:925-930

Le Corre M, Cherel Y, Lagarde F, Lormée H, Jouventin P (2003) Seasonal and inter-annual variation in the feeding ecology of a tropical oceanic seabird, the red-tailed tropicbird Phaeton rubricauda. Mar Ecol Prog Ser 255: 289-301

Milton DA, Smith GC, Blaber SJM (1996) Variable success in breeding of the roseate tern Sterna dougallii on the Northern Great Barrier Reef. Emu 96:123-131

Monaghan P, Uttley JD, Burns MD (1992) Effects of changes in food availability on reproductive effort in Arctic terns. Ardea 80:71-81

Nager RG, van Noordwijk AJ (1995) Proximate and ultimate aspects of phenotypic plasticity in timing of great tit breeding in a heterogeneous environment. Am Nat 146: $454-474$

New AL, Stansfield K, Smythe-Wright D, Smeed DA, Evans AJ, Alderson SG (2005) Physical and biochemical aspects of the flow across the Mascarene Plateau in the Indian Ocean. Philos Trans R Soc Lond A 363:151-168

New AL, Alderson SG, Smeed DA, Stansfield KL (2007) On the circulation of water masses across the Mascarene Plateau in the south Indian Ocean. Deep-Sea Res I 54:42-74

Nzioka RM (1979) Observations on the spawning seasons of East African reef fishes. J Fish Biol 14:329-342

Perrins CM (1970) The timing of bird's breeding seasons. Ibis 112:243-255

Pettifor RA, Perrins CM, McCleery RH (1988) Individual optimisation of clutch size in great tit. Nature 266:160-162

Piontkovki SA, Williams R (1995) Multiscale variability of tropical ocean zooplankton biomass. ICES J Mar Sci 52: 643-656

Platt T, Fuentes-Yaco C, Frank KT (2003) Spring algal bloom and larval fish survival. Nature 423:398-399

Quartly GD, Srokosz MA (2004) Eddies in the southern Mozambique Channel. Deep-Sea Res II 51:69-83

Ramos JA (2000) Characteristics of foraging habitats and chick food provisioning by tropical roseate terns. Condor 102:795-803

Ramos JA, Maul AM, Ayrton V, Bullock I and 5 others (2002) Influence of local and large-scale weather events and timing of breeding on tropical roseate tern reproductive parameters. Mar Ecol Prog Ser 243:271-279

Ramos JA, Bowler J, Betts M, Pacheco C, Agombar J, Bullock I, Monticelli D (2005) Productivity of white-tailed tropicbird on Aride Island, Seychelles. Waterbirds 28:405-410

Ramos JA, Maul AM, Bowler J, Wood L, Threadgold R, Johnson S, Birch D, Walker S (2006) Annual variation in laying date and breeding success of brown noddies on Aride Island, Seychelles. Emu 106:81-86

Reynolds RW, Rayner NA, Smith TM, Stokes DC, Wang W (2002) An improved in situ and satellite SST analysis for climate. J. Clim 15:1609-1625

Editorial responsibility: Otto Kinne (Editor-in-Chief), Oldendorf/Luhe, Germany
Robinson CJ (2004) Responses of the northern anchovy to the dynamics of the pelagic environment: identification of fish behaviours that may leave the population under risk of overexploitation. J Fish Biol 64:1072-1087

Safina C, Burger J (1988) Prey dynamics and the breeding phenology of common terns (Sterna hirundo). Auk 105: $720-726$

Safina C, Burger J, Gochfeld M, Wagner RH (1988) Evidence for prey limitation of common and roseate tern reproduction. Condor 90:852-859

Saji NH, Goswami BN, Vinayachandran PN, Yamagata T (1999) A dipole mode in the tropical Indian Ocean. Nature 401:360-363

Schott FA, McCreary JP (2001) The monsoon circulation of the Indian Ocean. Prog Oceanogr 51:1-123

Smithers BV, Peck DR, Krockenberger AK, Congdon BC (2003) Elevated sea-surface temperature, reduced provisioning and reproductive failure of wedge-tailed shearwaters (Puffinus pacificus) in the southern Great Barrier Reef, Australia. Mar Freshw Res 54:973-977

Suddaby D, Ratcliffe N (1997) The effects of fluctuating food availability on breeding Arctic terns (Sterna paradisaea). Auk 114:524-530

Surman CA, Wooller RD (2003) Comparative foraging ecology of five sympatric terns at a sub-tropical island in the eastern Indian Ocean. J Zool 259:219-230

Sydeman WJ, Penniman JF, Penniman TM, Pyle P, Ainley DG (1991) Breeding performance in the western gull: effects of parental age, timing of breeding and year in relation to food availability. J Anim Ecol 60:135-149

Vargas FH, Harisson S, Rea S, MacDonald DW (2006) Biological effects of El Niño on the Galapagos penguin. Biol Conserv 127:107-114

Webster PJ, Moore AM, Loschnigg JP, Leben TT (1999) Coupled ocean-atmosphere dynamics in the Indian Ocean during 1997-1998. Nature 401:356-360

White TCR (2004) Limitation of populations by weather-driven changes in food: a challenge to density-dependent regulation. Oikos 105:664-666

Whittingham MJ, Stephens PA, Bradbury RB, Freckleton RP (2006) Why do we still use stepwise modelling in ecology and behaviour? J Anim Ecol 75:1182-1189

Wolter K, Timlin MS (1993) Monitoring ENSO in COADS with a seasonally adjusted principal component index. In: Proc 17th Climate Diagnostics Workshop. NOAA/NMC/CAC, NSSL, Oklahoma Climate Survey, CIMMS and the School of Meteorology, University of Oklahoma, Norman, OK, p 52-57

Xie SP, Annamalai H, Schott FA, McCreary JP (2002) Structure and mechanisms of south Indian Ocean climate variability. J Clim 15:864-878

Yu W, Xinag B, Liu L, Liu N (2005) Understanding the origins of inter-annual thermocline variations in the tropical Indian Ocean, Geophys Res Lett 32: L24706

Zar JH (1999) Biostatistical analysis, 4th edn. Prentice Hall, Upper Saddle River, NJ

Zubkov MV, Quartly GD (2003) Ultraplankton distribution in surface waters of the Mozambique Channel: flow cytometry and satellite imagery. Aquat Microb Ecol 33: 155-161

Submitted: December 8, 2006; Accepted: June 21, 2007

Proofs received from author(s): November 23, 2007 